\title{
Penerapan Model Pembelajaran Problem Based Learning dengan Pendekatan Sains Teknologi Masyarakat untuk Meningkatkan Kualitas Pembelajaran Biologi Siswa Kelas XI.IPA 5 SMA Negeri 1 Karanganyar Tahun Pelajaran 2012/2013
}

\author{
Implementation of Problem Based Learning Model with Science Technology Society Approach \\ to Improve Quality of Biology Learning in Class XI.IPA 5 at SMA Negeri 1 Karanganyar \\ In Academic Year 2012/2013
}

\author{
Kusumawardani, Suciati Sudarisman, Meti Indrowati \\ Pendidikan Biologi FKIP Universitas Sebelas Maret \\ Email: wardanikus@gmail.com
}

Diterima 7 Agustus 2013, disetujui 8 September 2013

\begin{abstract}
The purpose of this research was to improve quality of biology learning considered by teacher's performance, utility of facilities in the classroom, classroom climate, student's scientific attitude, and student motivation to learn in class XI.IPA 5 SMA Negeri 1 Karanganyar academic year 2012/2013. This research was a Classroom Action Research which performed in three cycles. Each cycle consisted of 4 phases; planning, action, observation, and reflection. The data was collected by questionnaire, observation, and interview. Data validation was used triangulation of methods and triangulation of observers. The obtained data were analyzed using descriptive technique. Result of the research showed that according triangulation the average percentage for teacher's performance in pre cycle $(63.96 \%)$, cycle I $(90.21 \%)$, cycle II $(95.83 \%)$ and cycle III $(100 \%)$; classroom climate pre cycle $(70.22 \%)$, cycle I $(86.43 \%)$, cycle II $(83.30 \%)$ and cycle III (84.65\%); student's scientific attitude pre cycle $(69.31 \%)$, cycle I $(76.20 \%)$, cycle II (77.61\%) and cycle III $(83.45 \%)$; and student motivation to learn pre cycle $(67.01 \%)$, cycle I $(70.33 \%)$, cycle II $(73.97 \%)$ and cycle III (77.69\%); utility of learning facilities in the classroom have been optimally. The results showed that the average percentage quality of biology learning aspect such as pre cycle $(67.63 \%)$, cycle I $(80.79 \%)$, cycle II $(82.68 \%)$ and cycle III $(86.45 \%)$. The quality of biology learning was increase $18.82 \%$ from pre cycle to cycle III. Cycles stopped in cycle III because the research target was achieved. The conclusion describes that the implementation of problem based learning with science technology society approach was able to improve the quality of biology learning considered by teacher's performance, utility of facilities in the classroom, classroom climate, student's scientific attitude, and student motivation to learn in class XI.IPA 5 at SMA Negeri 1 Karanganyar in academic year 2012/2013.
\end{abstract}

Key Words: Problem Based Learning, Science Technology Society Approach, Quality of Biology Learning

\section{Pendahuluan}

Tidak dipungkiri bahwa kualitas pembelajaran yang meliputi lima aspek yaitu kemanfaatan fasilitas pembelajaran, performance guru, iklim kelas, sikap ilmiah, dan motivasi belajar siswa belum sesuai dengan harapan. Hasil observasi di kelas XI.IPA 5 SMA Negeri 1 Karanganyar menunjukkan adanya ketersediaan fasilitas yang lengkap belum didukung penggunaan yang optimal terutama pada fasilitas laboratorium. Praktikum jarang dilakukan. Pembelajaran selama ini lebih sering menggunakan 
metode ceramah. Penggunaan metode ini tidak banyak mengasah keterampilan atau kompetensi guru dalam mengajar di kelas (performance guru). Performance guru hasil observasi pra tindakan sebesar $63,96 \%$. Siswa hanya mendengarkan penjelasan guru dan membuat catatan. Sikap ilmiah siswa kurang dikembangkan. Hasil capaian sikap ilmiah siswa pada saat pra tindakan adalah sebesar $69,32 \%$. Siswa juga cenderung belajar sendiri-sendiri. Interaksi antar siswa menjadi terbatas. Hal ini memunculkan iklim kelas yang kurang kondusif. Iklim kelas siswa pada saat pra tindakan sebesar 70,22\%.

Pada era globalisasi ini perkembangan teknologi informasi yang demikian pesat telah mendorong terjalinnya kerjasama internasional di berbagai aspek kehidupan. Namun demikian di sisi lain persaingan hidup menjadi semakin ketat. Dibutuhkan sumber daya manusia yang bermutu tinggi untuk dapat bertahan dan memenangkan persaingan. Pendidikan sebagai sarana untuk membentuk sumber daya manusia sudah seharusnya menyesuaikan dengan tuntutan zaman melalui perbaikan kualitas secara terus menerus. Hal ini dapat dilakukan salah satunya dengan selalu meningkatkan kualitas pembelajaran di kelas. Pembelajaran di kelas seharusnya tidak hanya menekankan pada segi kognitif tanpa membekali siswa dengan keterampilan lain yang bermanfaat bagi kehidupan.

Pada pembelajaran biologi siswa tidak seharusnya hanya dibiasakan hanya menghafal konsep-konsep sains. Biologi merupakan bagian dari sains yang memiliki karakteristik spesifik yakni mengacu pada tiga aspek yang meliputi proses (hands on), produk (minds on), dan sikap ilmiah (heart on).

Berdasarkan uraian di atas ada kesenjangan antara tuntutan kualitas pembelajaran biologi yang meliputi: (1) Performance guru; (2) Kemanfaatan fasilitas pembelajaran; (3) Iklim kelas; (4) Sikap ilmiah; dan (5) Motivasi belajar, dengan fakta yang terjadi di lapangan. Oleh karena adanya permasalahan tersebut harus dicari solusinya dengan penerapan pembelajaran yang mampu mengaktifkan guru dan siswa dalam pembelajaran melalui keterampilan proses sains.

Model Problem Based Learning (PBL) merupakan inovasi dalam pembelajaran karena dalam PBL kemampuan berpikir siswa betul-betul dioptimalisasikan melalui proses kerja kelompok atau tim yang sistematis, sehingga siswa dapat memberdayakan, mengasah, menguji, dan mengembangkan kemampuan berpikirnya secara berkesinambungan (Tan, dalam Rusman 2010:229). Sintaks PBL terdiri dari lima fase yaitu fase 
memberikan orientasi tentang permasalahan kepada siswa, fase mengorganisasikan siswa untuk meneliti, fase membantu investigasi mandiri dan kelompok, fase mengembangkan artefak dan exhibit, fase menganalisis dan mengevaluasi proses mengatasi masalah (Arends, 2008).

Model PBL memiliki sejumlah kelebihan yaitu sebagai berikut: (1) Dapat meningkatkan motivasi belajar karena menggunakan permasalahan yang relevan dengan kehidupan nyata dan menimbulkan ketertarikan bagi siswa sehingga semakin meningkatkan motivasi belajar; (2) Pemahaman siswa akan menjadi lebih baik ketika siswa mampu mengaitkan pengetahuan baru dengan pengetahuan lama sebagai pengetahuan pra syarat; (3) Mengembangkan kemampuan berpikir tingkat tinggi karena melalui permasalahan yang tidak mudah diprediksi siswa akan berusaha mengumpulkan informasi, menganalisa data, dan menguji hipotesis, sehingga siswa belajar bagaimana belajar (learning how to learn) (Choo Ong \& Borich, 2006).

Penerapan model PBL dalam materi transport zat melalui membran sel akan lebih efektif jika dipadukan dengan pendekatan yang tepat. Pendekatan Sains Teknologi Masyarakat (STM) merupakan pendekatan yang menekankan adanya keterkaitan antara sains, teknologi, dan masyarakat. Konsep-konsep sains diha- rapkan dapat mengatasi permasalahanpermasalahan yang muncul di masyarakat melalui penemuan-penemuan teknologi. Pembelajaran menggunakan pendekatan STM dapat mengembangkan keterampilan kognitif, keterampilan afektif dan keterampilan psikomotor (Poedjiadi, 2010).

Penggunaan model PBL dengan pendekatan STM diharapkan membuat siswa lebih tertarik dan antusias dalam mengikuti pembelajaran biologi. Ketertarikan siswa terhadap pembelajaran akan meningkatkan motivasi belajar siswa. Siswa menjadi lebih aktif dan senang dalam melakukan kegiatan-kegiatan untuk mencapai prestasi. Melalui penyelidikan kelompok diharapkan dapat mengembangkan sikap ilmiah dan keterampilan sosial sehingga iklim kelas menjadi lebih kondusif. Penggunaan alat-alat laboratorium sebagai sarana melakukan penyelidikan akan meningkatkan kemanfaatan fasilitas. Peran guru dalam pembelajaran bukan lagi sebagai sumber informasi namun sebagai fasilitator dan motivator sehingga diharapkan performance guru akan meningkat.

Penelitian ini bertujuan menerapkan model pembelajaran PBL dengan pendekatan STM untuk meningkatkan kualitas pembelajaran biologi (meliputi aspek kemanfaatan fasilitas pembelaja- 
ran, performance guru dalam kelas, iklim kelas, sikap ilmiah siswa, dan motivasi belajar) di kelas XI.IPA 5 SMA Negeri 1 Karanganyar Tahun Pelajaran 2012/2013.

\section{Metode Penelitian}

Penelitian ini merupakan Penelitian Tindakan Kelas (PTK) yang dilaksanakan dalam tiga siklus. Setiap siklus terdiri dari 4 tahapan yaitu perencanaan, tindakan, observasi, dan refleksi. Subjek penelitian adalah siswa kelas XI.IPA 5 SMA Negeri 1 Karanganyar Tahun Pelajaran 2012/2013. Penelitian ini menggunakan tiga sumber data penting yang disajikan sebagai sasaran pengambilan dan pengumpulan data serta informasi penelitian. Sumber data tersebut meliputi: (1) tempat dan peristiwa; (2)informan; (3)dokumen.

Teknik yang digunakan untuk mengumpulkan data berupa instrumen angket, lembar observasi dan wawancara disertai data pendukung berupa hasil belajar kognitif, afektif, dan psikomotor.

Teknik analisis yang digunakan dalam penelitian adalah deskriptif berdasarkan hasil observasi dan refleksi dari tiap-tiap siklus. Teknik analisis kualitatif mengacu pada model analisis Miles dan Huberman (1992). Langkahlangkah operasional penelitian yang digunakan mengikuti model pengembangan oleh Mc.Taggrat berupa model spiral meliputi tahap perencanaan, tahap pelaksanaan, tahap pengamatan, dan tahap refleksi. Penelitian dapat dihentikan apabila rata-rata capaian indikator yang diukur sudah mencapai target yang ditentukan oleh guru dan peneliti yaitu $\geq 75 \%$ (BSNP 2006).

\section{Hasil dan Pembahasan}

Hasil penelitian di kelas XI.IPA 5 Negeri 1 Karanganyar Tahun Pelajaran 2012/2013 menunjukkan bahwa penerapan pendekatan PBL dengan pendekatan STM dapat meningkatkan kualitas pembelajaran biologi. Peningkatan kualitas pembelajaran biologi tersebut meliputi:

\section{Kemanfaatan Fasilitas Pembelajaran}

Penerapan model PBL dengan pendekatan STM dalam pembelajaran membutuhkan sarana yang lebih kompleks dibandingkan pada saat menggunakan metode ceramah. Sintaks PBL secara garis besar terdiri dari lima fase. Masing-masing fase membutuhkan sarana yang berbeda. Pada fase mengorientasikan siswa pada masalah, guru menyediakan media berupa wacana dan gambar dilengkapi penggunaan LCD untuk menayangkan video. Penggunaan video dimaksudkan untuk meningkatkan rasa ingin tahu siswa terhadap permasalahan. Pada fase membimbing penyelidi- 
kan individual dan kelompok, guru menyediakan sarana berupa alat-alat laboratorium untuk melakukan eksperimen. Di akhir pembelajaran guru menampilkan video animasi untuk mempermudah pemahaman siswa mengenai materi. Fasilitas pembelajaran pada saat penerapan model PBL dengan pendekatan STM menjadi terfungsikan dengan lebih optimal.

\section{Performance Guru dalam Kelas}

\section{Performance guru merupakan aspek yang sangat menentukan keberhasilan pembelajaran. Secara lebih lengkap capaian hasil persentase tiap indikator performance guru pada pra siklus, siklus I, siklus II, dan siklus III disajikan pada Tabel 1 .}

Tabel 1. Perbandingan persentase tiap indikator performance guru pra siklus, siklusI, siklusII dan siklus III

\begin{tabular}{|c|c|c|c|c|c|}
\hline \multirow[t]{2}{*}{ No } & \multirow[t]{2}{*}{ Indikator } & \multicolumn{4}{|c|}{ Capaian Indikator (\%) } \\
\hline & & $\begin{array}{l}\text { Pra } \\
\text { Siklus }\end{array}$ & $\begin{array}{l}\text { Si- } \\
\text { klus } \\
\text { I } \\
\end{array}$ & $\begin{array}{l}\text { Siklus } \\
\text { II }\end{array}$ & $\begin{array}{l}\text { Si- } \\
\text { klus } \\
\text { III }\end{array}$ \\
\hline 1 & $\begin{array}{l}\text { Kemampuan } \\
\text { membuka } \\
\text { pelajaran }\end{array}$ & 20 & 80 & 100 & 100 \\
\hline 2 & $\begin{array}{l}\text { Sikap guru } \\
\text { dalam proses } \\
\text { pembelajaran }\end{array}$ & 100 & 100 & 100 & 100 \\
\hline 3 & $\begin{array}{l}\text { Penguasaan } \\
\text { bahan belajar }\end{array}$ & 75 & 75 & 100 & 100 \\
\hline 4 & $\begin{array}{l}\text { Kegiatan } \\
\text { belajar } \\
\text { mengajar }\end{array}$ & 50 & 100 & 100 & 100 \\
\hline 5 & $\begin{array}{l}\text { Kemampuan } \\
\text { menggunakan } \\
\text { media } \\
\text { pembelajaran }\end{array}$ & 100 & 100 & 100 & 100 \\
\hline 6 & $\begin{array}{l}\text { Evaluasi } \\
\text { pembelajaran }\end{array}$ & 100 & 100 & 100 & 100 \\
\hline 7 & $\begin{array}{l}\text { Kemampuan } \\
\text { menutup } \\
\text { kegiatan } \\
\text { pembelajaran }\end{array}$ & 33,33 & 100 & 100 & 100 \\
\hline 8 & $\begin{array}{l}\text { Tindak } \\
\text { lanjut/follow } \\
\text { up. }\end{array}$ & 33.33 & 67 & 67 & 100 \\
\hline
\end{tabular}

\begin{tabular}{cccccc}
\hline No & Indikator & \multicolumn{4}{l}{ Capaian Indikator (\%) } \\
& & $\begin{array}{l}\text { Pra } \\
\text { Siklus }\end{array}$ & $\begin{array}{l}\text { Si- } \\
\text { klus } \\
\text { I }\end{array}$ & $\begin{array}{l}\text { Siklus } \\
\text { II }\end{array}$ & $\begin{array}{l}\text { Si- } \\
\text { klus } \\
\text { III }\end{array}$ \\
\hline & & & & \\
\hline & & & 95.83 & 100 \\
& Rata-rata & 63,96 & & & \\
& & 90.2 & & \\
& & 1 &
\end{tabular}

Hasil capaian persentase performance guru pada siklus I, siklus II, dan siklus III disajikan pada Gambar 1.

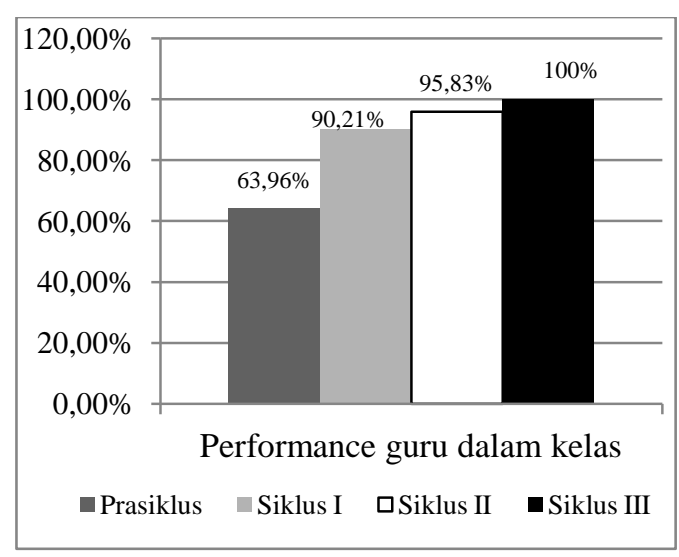

Gambar 1. Diagram Perubahan Persentase Capaian Aspek Performance Guru Dalam Kelas Pada Prasiklus, Siklus I, Siklus II Dan Siklus II

Penerapan model pembelajaran PBL dengan pendekatan STM telah menggeser peran guru sebagai pakar atau pemegang kewenangan formal pada saat menggunakan metode ceramah menjadi fasilitator, pembimbing atau konsultan profesional. Pergeseran peran ini ternyata membawa dampak yang sangat baik bagi peningkatan aspek performance guru. Pada saat guru berperan sebagai pakar maka fungsi guru terbatas pada menyampaikan informasi sebanyakbanyaknya kepada siswa. Pada saat penerapan model PBL dengan pendekatan STM pembelajaran menjadi 
lebih kompleks sehingga secara otomatis guru sebagai fasilitator harus mengembangkan kemampuan yang mendukung keberhasilan pembelajaran. Kemampuan guru yang berkembang pada saat menggunakan model pembelajaran PBL dengan pendekatan STM antara lain: kemampuan menjalankan pembelajaran sesuai sintaks dalam RPP, keterampilan menanggapi dan merespon pertanyaan siswa, ketepatan dalam menggunakan alokasi waktu yang disediakan, kemampuan menggunakan media yang bervariasi, dan membantu meningkatkan perhatian siswa dalam pembelajaran. Menurut Darling et al (2000: 23), hasil analisis secara kuantitatif, kualitas guru mempunyai korelasi positif dan signifikan terhadap prestasi belajar siswa. Artinya jika kualitas guru baik maka akan berpengaruh baik juga terhadap peningkatan prestasi belajar siswa.

\section{Sikap Ilmiah}

Sikap ilmiah merupakan sikap positif yang dikaitkan dengan keilmuan. Sikap ilmiah siswa mengalami peningkatan yang cukup signifikan selama penerapan model PBL dengan pendekatan STM. Perbandingan persentase tiap indikator sikap ilmiah pada pra siklus, siklus I, siklus II, dan siklus III disajikan pada Tabel 2.
Tabel 2. Perbandingan Capaian lndikator Sikap Ilmiah Berdasarkan Lembar Observasi dan Angket Prasiklus, Siklus I, Siklus II dan Siklus III

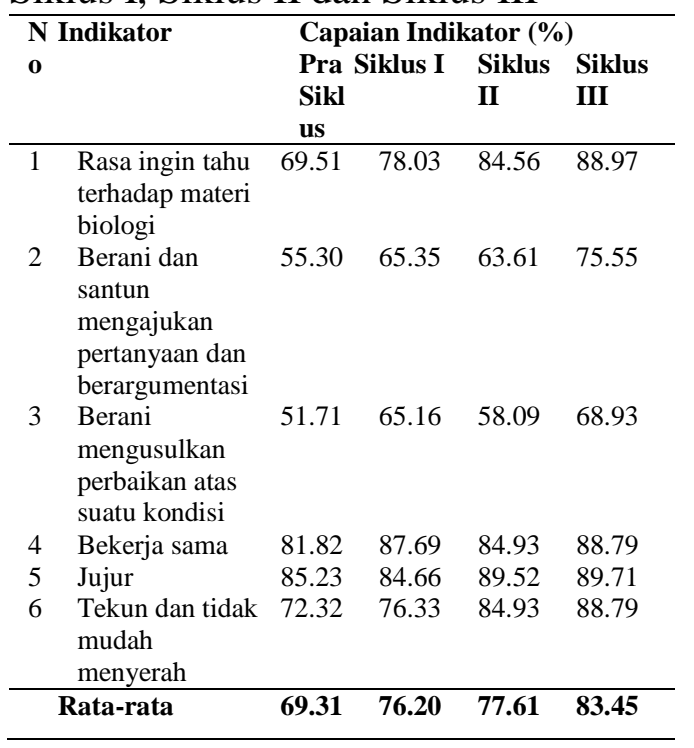

Diagram perubahan persentase capaian aspek sikap ilmiah pada prasiklus, siklus I, siklus II dan siklus III disajikan pada Gambar 2.

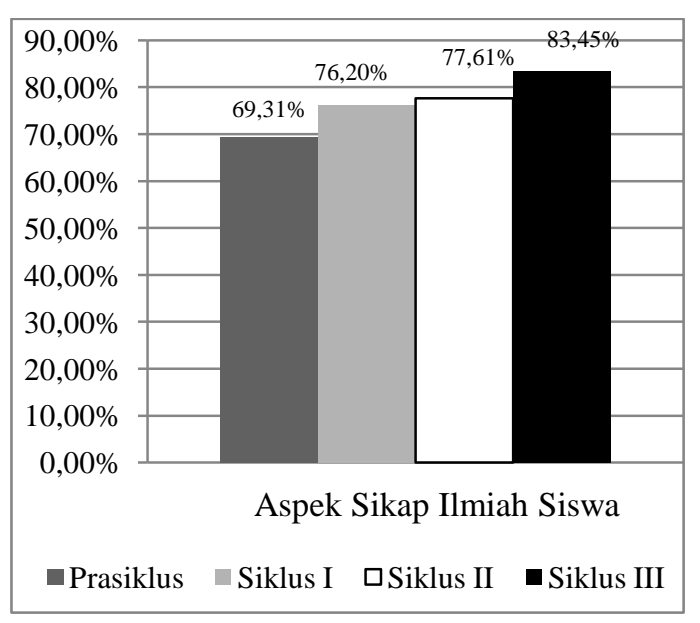

Gambar 2. Diagram Perubahan Persentase Capaian Aspek Sikap Ilmiah Pada Prasiklus, Siklus I, Siklus II dan Siklus III

Pada pembelajaran dengan metode ceramah siswa hanya mendengarkan penjelasan guru dan jarang menunjukkan rasa ingin tahu dengan bertanya. Sikap 
siswa menjadi pasif. Pada saat penerapan model pembelajaran PBL dengan pendekatan STM pembelajaran didahului dengan memberikan wacana mengenai suatu permasalahan yang relevan dengan kehidupan nyata. Rasa ingin tahu berkembang pada saat siswa merumuskan sendiri permasalahan-permasalahan yang ada dalam wacana. Keberanian siswa memberikan argumentasi terlihat pada saat proses diskusi kelompok maupun presentasi. Pada tahap penyelidikan kelompok berupa merancang dan melakukan percobaan, siswa berlatih untuk berpikir kritis. Ketekunan dan sikap pantang menyerah juga sangat teruji pada saat siswa melakukan praktikum sebab terkadang praktikum tidak berjalan sesuai yang diharapkan. Siswa dilatih untuk peduli mengenai isuisu yang terjadi di lingkungan. Siswa harus berpikir kritis mengaitkan antara permasalahan yang ada dengan teknologi terkini yang sekiranya dapat dijadikan solusi. Kepedulian siswa terhadap masyarakat berkembang pada saat siswa membuat poster sebagai bentuk kampanye kepedulian lingkungan.

Penerapan model PBL dengan pendekatan STM sesuai dengan teori pembelajaran konstruktivis bahwa guru tidak hanya memberikan pengetahuan (transfer of knowledge) kepada siswa, melainkan siswa harus membangun sendiri pengetahuan didalam benaknya. Guru dapat memberikan kemudahan untuk proses ini dengan memberi kesempatan siswa untuk menemukan atau menerapkan ide-ide mereka sendiri salah satunya melalui proses penyelidikan (melakukan eksperimen) dalam pembelajaran. Sesuai dengan teori Piaget (Trianto, 2011) bahwa dalam pembelajaran seharusnya memusatkan perhatian pada berpikir atau proses mental anak tidak sekedar pada hasil.

\section{Iklim Kelas}

Iklim kelas yang kondusif akan sangat mendukung keberhasilan pembelajaran. Perbandingan capaian indikator iklim kelas pra siklus, siklus I, siklus II, dan siklus III disajikan pada Tabel 3.

Tabel 3. Perbandingan Capaian Indikator Iklim Kelas Prasiklus, Siklus I, Siklus II dan Siklus III

\begin{tabular}{|c|c|c|c|c|c|}
\hline \multirow{2}{*}{$\begin{array}{l}\mathbf{N} \\
\mathbf{o}\end{array}$} & \multirow[t]{2}{*}{ Indikator } & \multicolumn{4}{|c|}{ Capaian Indikator (\%) } \\
\hline & & $\begin{array}{l}\text { Pra } \\
\text { siklus }\end{array}$ & $\begin{array}{l}\text { Siklus } \\
\text { I }\end{array}$ & $\begin{array}{l}\text { Siklus } \\
\text { II }\end{array}$ & $\begin{array}{l}\text { Siklus } \\
\text { III }\end{array}$ \\
\hline 1 & $\begin{array}{l}\text { Kekompa } \\
\text { kan siswa }\end{array}$ & 64.21 & 86.93 & 83.65 & 87.59 \\
\hline 2 & $\begin{array}{l}\text { Keterlibat } \\
\text { an siswa } \\
\text { dalam } \\
\text { pembelaja } \\
\text { ran }\end{array}$ & 80.02 & 89.87 & 88.33 & 88.15 \\
\hline 3 & $\begin{array}{l}\text { Kepuasan } \\
\text { siswa }\end{array}$ & 66.01 & 78.89 & 75.38 & 73.62 \\
\hline 4 & $\begin{array}{l}\text { Dukungan } \\
\text { guru } \\
\text { dalam } \\
\text { kegiatan } \\
\text { pembelaja } \\
\text { ran }\end{array}$ & 70.65 & 90.06 & 85.87 & 89.25 \\
\hline & Rata-rata & 70.22 & 86.43 & 83.30 & 84.65 \\
\hline
\end{tabular}

Adapun perbandingan capaian iklim kelas pra siklus, siklus I, siklus II 
dan siklus III secara keseluruhan disajikan pada Gambar 3.

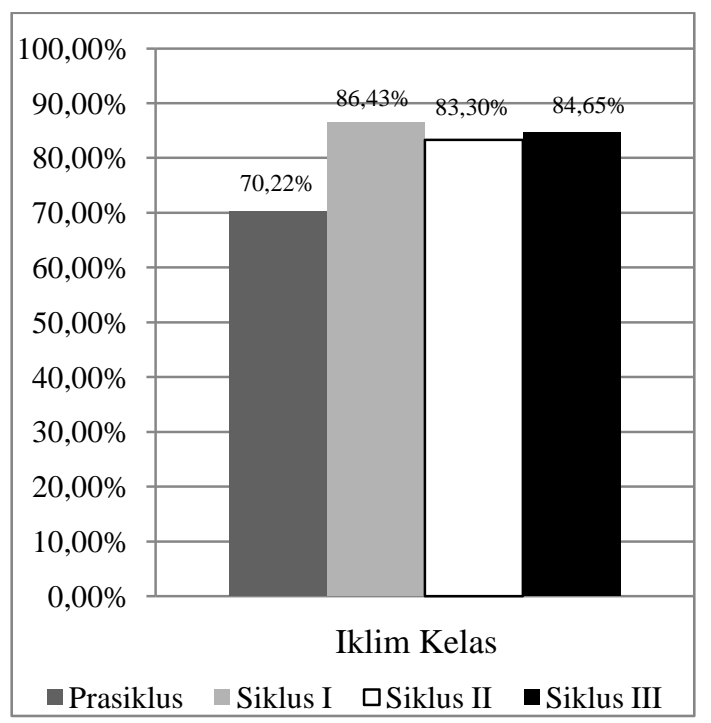

Gambar 3. Perbandingan capaian iklim kelas pra siklus, siklus I, siklus II dan siklus III

Selama menggunakan model pembelajaran PBL dengan pendekatan STM iklim kelas mengalami kenaikan yang cukup signifikan. Hal ini dikarenakan pembelajaran tidak lagi terpusat pada guru. Siswa menjadi lebih aktif. Siswa bekerja dalam lingkungan yang kolaboratif. Pada kenyataannya manusia sebagai makhluk sosial tidak dapat hidup sendiri. Manusia selalu membutuhkan oranglain untuk memecahkan berbagai masalah dalam kehidupannya. Tidak terkecuali dalam hal belajar, bantuan dari orang lain akan dapat membantu meningkatkan pemahaman siswa. Hal ini sesuai dengan teori Vygotsky (Arends, 2008) yang menekankan pentingnya aspek sosial dalam belajar.
Pada saat diskusi siswa berlatih untuk mengungkapkan argumentasi. Siswa juga berlatih untuk menghargai temannya dengan mendengarkan dan memberi perhatian ketika temannya sedang berbicara. Sikap saling menghargai ini meningkatkan hubungan antar siswa. Hubungan antara guru dan siswa juga ternyata menjadi semakin baik. Siswa terlihat lebih berani bertanya pada guru jika mengalami kesulitan. Guru menanggapi setiap pertanyaan dengan baik.

\section{Motivasi Belajar}

Motivasi belajar dalam hal ini difokuskan pada motivasi berprestasi merupakan dorongan dalam diri siswa untuk belajar, mengerjakan tugas-tugas, memecahkan masalah dengan sebaikbaiknya. Perbandingan capaian indikator motivasi belajar pra siklus, siklus I, siklus II, dan siklus III disajikan pada Tabel 4.

Tabel 4. Perbandingan capaian indikator motivasi belajar pra siklus, siklus I, siklus II, dan siklus II

\begin{tabular}{|c|c|c|c|c|c|}
\hline \multirow[t]{2}{*}{ No } & \multirow[t]{2}{*}{ Indikator } & \multicolumn{4}{|c|}{ Capaian Indikator (\%) } \\
\hline & & $\begin{array}{l}\text { Prasikl } \\
\text { us }\end{array}$ & $\begin{array}{l}\text { Siklus } \\
\text { I }\end{array}$ & $\begin{array}{l}\text { Siklus } \\
\text { II }\end{array}$ & $\begin{array}{l}\text { Siklus } \\
\text { III }\end{array}$ \\
\hline 1 & & 63.84 & 75.01 & 70.60 & 80.34 \\
\hline 2 & & 80.50 & 82.20 & 88.51 & 87.87 \\
\hline 3 & & 64.78 & 61.56 & 61.22 & 69.67 \\
\hline 4 & & 74.06 & 76.33 & 72.61 & 87.32 \\
\hline 5 & & 62.69 & 72.54 & 74.62 & 68.57 \\
\hline 6 & & 76.14 & 74.62 & 80.52 & 85.48 \\
\hline 7 & & 57.78 & 55.31 & 63.96 & 67.83 \\
\hline 8 & & 61.65 & 76.52 & 77.02 & 72.52 \\
\hline 9 & & 61.77 & 65.73 & 76.66 & 79.60 \\
\hline & Jumlah & 67.02 & 71.09 & 73.97 & 77.69 \\
\hline
\end{tabular}




\begin{tabular}{|c|c|c|c|c|c|}
\hline \multirow[t]{2}{*}{ No } & \multirow{2}{*}{ Indikator } & \multicolumn{4}{|c|}{ Capaian Indikator (\%) } \\
\hline & & $\begin{array}{l}\text { Prasikl } \\
\text { us }\end{array}$ & $\begin{array}{l}\text { Siklus } \\
\text { I }\end{array}$ & $\begin{array}{l}\text { Siklus } \\
\text { II }\end{array}$ & $\begin{array}{l}\text { Siklus } \\
\text { III }\end{array}$ \\
\hline
\end{tabular}

Keterangan indikator:

1. Sensitif terhadap hal-hal yang berkaitan dengan peningkatan prestasi

2. Kegiatan untuk mencapai prestasi

3. Cermat menentukan target prestasi

4. Usaha menanggulangi berbagai penghambat dalam pencapaian

prestasi

5. Menemukan suatu cara penyelesaian masalah yang lebih singkat dan mudah

6. Menyukai tantangan baik dari dalam maupun luar

7. Kesempurnaan penyelesaian tugas

8. Melakukan kegiatan diskusi dengan baik

9. Percaya diri dan tangguh dalam pembelajaran dan

Perbandingan persentase capaian motivasi belajar siswa pra siklus, siklus I, siklus II, dan siklus II dalam bentuk diagram disajikan pada Gambar 4.

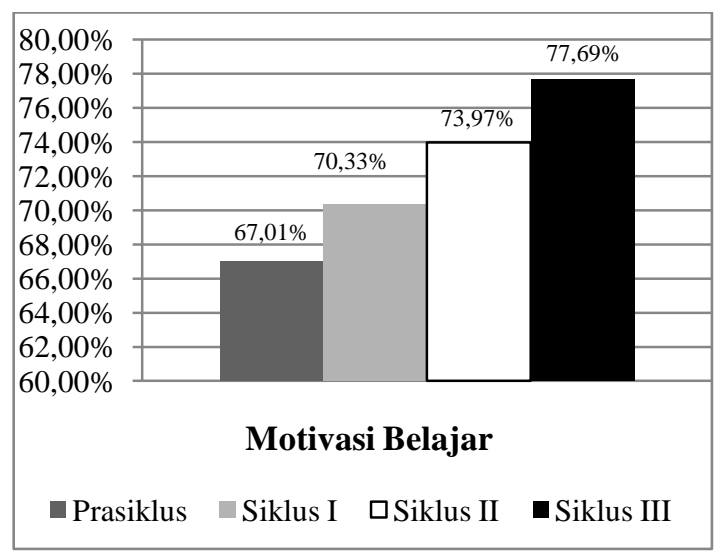

Gambar 4. Capaian persentase motivasi belajar siklus I, siklus II, dan siklus III

Motivasi belajar siswa dapat ditingkatkan dengan penerapan model pembelajaran PBL dengan pendekatan STM. Pada penerapan model ini siswa dibawa pada masalah nyata yang terjadi dalam kehidupan sehari-hari sehingga rasa ingin tahu siswa meningkat. Ketertarikan siswa pada pembelajaran meningkatkan motivasi siswa. Hal ini didukung pula dengan adanya penyelidikan kelompok berupa prakti- kum. Siswa dilatih untuk menemukan konsep dalam pembelajaran. Siswa menjadi jauh lebih aktif melakukan berbagai usaha untuk mencapai keberhasilan selama proses pembelajaran. Sesuai dengan teori Ausubel (Dahar, 2011) bahwa salah satu dimensi dalam pembelajaran bermakna berhubungan dengan cara informasi atau materi pelajaran yang disajikan kepada siswa, melalui penerimaan atau penemuan.

Berdasarkan uraian tiap aspek kualitas pembelajaran di atas dapat diketahui persentase capaian kualitas pembelajaran pra siklus, siklus I, siklus II, dan siklus III disajikan pada Tabel 5 dan Gambar 5

Tabel 5 Perbandingan Capaian Aspek Kualitas Pembelajaran Biologi Prasiklus, Siklus I, Siklus II, dan Siklus III

\begin{tabular}{|c|c|c|c|c|c|}
\hline \multirow{2}{*}{$\begin{array}{l}\mathbf{N} \\
\mathbf{0}\end{array}$} & \multirow{2}{*}{ Indikator } & \multicolumn{4}{|c|}{ Capaian Indikator (\%) } \\
\hline & & $\begin{array}{l}\text { Prasiklu } \\
\text { S }\end{array}$ & $\begin{array}{l}\text { Siklu } \\
\text { S I }\end{array}$ & $\begin{array}{l}\text { Siklus } \\
\text { II }\end{array}$ & $\begin{array}{l}\text { Siklu } \\
\text { s III }\end{array}$ \\
\hline 1 & $\begin{array}{l}\text { Perfor- } \\
\text { mance guru }\end{array}$ & 63.96 & 90.21 & $\begin{array}{l}95.8 \\
3\end{array}$ & 100 \\
\hline 2 & Iklim kelas & 70.22 & 86.43 & 83.30 & 84.65 \\
\hline 3 & $\begin{array}{l}\text { Sikap } \\
\text { ilmiah }\end{array}$ & 69.31 & 76.20 & 77.61 & 83.45 \\
\hline 4 & $\begin{array}{l}\text { Motivasi } \\
\text { berprestasi }\end{array}$ & 67.01 & 70.33 & 73.97 & 77.69 \\
\hline & Rata-rata & 67.63 & 80.79 & 82.68 & 86.45 \\
\hline
\end{tabular}

\begin{tabular}{|c|c|}
\hline $100,00 \%$ & $80,79 \% 82,68 \% 86,45 \%$ \\
\hline $80,00 \%$ & $67,63 \%$ \\
\hline $60,00 \%$ & \\
\hline $40,00 \%$ & \\
\hline $20,00 \%$ & \\
\hline \multicolumn{2}{|l|}{$0,00 \%$} \\
\hline \multicolumn{2}{|r|}{ Kualitas Pembelajaran Biologi } \\
\hline Prasiklus & $\square$ Siklus I $\square$ Siklus II $\square$ Siklus III \\
\hline
\end{tabular}


Gambar 5 Diagram Perbandingan Persentase Capaian Kualitas Pembelajaran Biologi Pra siklus, Siklus I, Siklus II, dan Siklus II

Berdasarkan Tabel 5 dan Gambar 5 diketahui persentase capaian kualitas pembelajaran biologi berdasarkan triangulasi dari pra siklus, siklus I, siklus II, dan siklus II mengalami peningkatan sebesar $18.82 \%$.

\section{Kesimpulan}

Berdasarkan hasil penelitian ini dapat disimpulkan bahwa penerapan model pembelajaran PBL dengan pendekatan STM mampu meningkatkan kualitas pembelajaran biologi di kelas XI.IPA 5 SMA Negeri 1 Karanganyar Tahun Pelajaran 2012/2013.

Hasil pencapaian masing-masing aspek meliputi performance guru prasiklus $(63,96 \%)$, siklus I $(90,21 \%)$, siklus II (95,83\%) dan siklus III (100\%); iklim kelas prasiklus $(70,22 \%)$, siklus I (86.43\%), siklus II $(83,30 \%)$ dan siklus III $(84,65 \%)$; sikap ilmiah prasiklus $(69,32 \%)$, siklus I $(76,20 \%)$, siklus II $(77,61 \%)$ dan siklus III $(83,45 \%)$; dan motivasi belajar prasiklus $(67,01 \%)$, siklus I (70,33\%), siklus II $(73,97 \%)$ dan siklus III (77,69\%); kemanfaatan fasilitas pembelajaran semakin meningkat ditunjukkan dari penggunaan fasilitas labolatorium untuk percobaan dan penggunaan LCD untuk menayangkan variasi media pembelajaran berupa video.

Hasil pencapaian aspek kualitas pembelajaran biologi secara keseluruhan prasiklus $(67,63 \%)$, siklus I $(80,79 \%)$, siklus II (82.68\%) dan siklus III $(86,45 \%)$. Adapun peningkatan aspek kualitas pembelajaran dari hasil prasiklus sampai siklus III sebesar 18,82\%.

\section{Daftar Pustaka}

Arends, R.I. 2008. Belajar untuk Mengajar Edisi Ketujuh. Terj. Soetjipto H.P. Yogyakarta: Pustaka Pelajar

Badan Penelitian dan Pengembangan. 2003. Kompetensi Dasar Biologi Kurikulum 2004. Jakarta: Departemen Pendidikan Nasional

Choo, O. A. and Borich, G.D. (Eds). 2006. Teaching Strategies that Promote Thinking: Models and Curriculum Approaches. Singapore: McGrawHill Education (Asia)

Dahar, R.W. 2011. Teori-Teori Belajar dan Pembelajaran. Bandung: Erlangga

Darling, L. 2000. Teacher Quality and Student Achievement. Journal Education Policy Analysis Archives. Vol.8(1) January 1, 2000. ISSN 10682341

Direktorat Tenaga Kependidikan. 2008. Penilaian Kinerja Guru. Jakarta: Departemen Pendidikan Nasional

Miles and Huberman. 1992. Data Kualitatif. Jakarta: UI Press

Poedjiadi, A. 2010. Sains Teknologi Masyarakat. Bandung: Rosdakarya

Rusman. 2011. Model-model Pembelajaran: Mengembangkan Profesionalisme Guru. Jakarta: Rajawali Pers 
Trianto. 2011. Mendesain Model Pembelajaran Inovatif-Progresif. Jakarta: Kencana
Widoyoko, S.E.P. 2011. Evaluasi Program Pembelajaran. Yogyakarta: Pustaka Pelajar 